\title{
Potassium ions modulate a G-quadruplex-ribozyme's activity
}

JEAN-DENIS BEAUDOIN and JEAN-PIERRE PERREAULT

RNA Group/Groupe ARN, Département de Biochimie, Faculté de Médecine et des Sciences de la Santé, Université de Sherbrooke, Sherbrooke QC, J1H 5N4 Canada

\begin{abstract}
Hepatitis delta virus ribozyme folds into a tightly packed tertiary structure. However, unlike other ribozymes, it does not appear to be able to follow alternative folding pathways. Molecular engineering of the hepatitis delta virus ribozyme led to the development of a ribozyme possessing an endoribonuclease activity that is under the control of a G-quadruplex structure (i.e., a G-quartzyme). This latter species represents an entirely new class of ribozyme. Mutants of this ribozyme were then generated in order to shed light on the modulation of the cleavage activity caused by the presence of the G-quadruplex structure. Kinetic characterization of the G-quartzyme was performed under various single turnover conditions. It was found to be active only in the presence of potassium cations that act as counter ions in the positioning of the four coplanar guanines that form the building block of the G-quadruplex structure. The G-quartzyme behaves as an allosteric ribozyme, with the potassium cations acting as positive effectors with a Hill coefficient of $2.9 \pm \mathbf{0 . 2}$. The conformation transition caused by the presence of the potassium ions is supported by enzymatic and chemical probing of both the inactive (off) and active (on) structures. This study shows that it is possible to interfere with the tight structure of the hepatitis delta virus ribozyme by adding an unusual, stable structure. To our knowledge, the G-quartzyme is the sole ribozyme that exhibits a monovalent cation-dependent activity.
\end{abstract}

Keywords: allosteric ribozyme; G-quadruplex; catalytic RNA; molecular engineering

\section{INTRODUCTION}

Molecular engineering of the hepatitis delta virus (HDV) ribozyme led to the creation of an allosteric ribozyme $(\mathrm{Rz})$ possessing an endoribonuclease activity that is under the control of a G-quadruplex structure. The HDV RNA strand that includes a self-cleaving RNA motif that has been separated into two molecules in order to develop transacting systems in which one molecule, identified as the ribozyme (HDV Rz), possesses the catalytic properties required to successively cleave several molecules of substrate (S) (Shih and Been 2002). HDV Rz folds into a tertiary structure that is extremely stable and that retains its activity at temperatures as high as $80^{\circ} \mathrm{C}$, as well as in denaturing buffer containing either $5 \mathrm{M}$ urea or $18 \mathrm{M}$ formamide (Doherty and Doudna 2000; Shih and Been 2002). Unlike other ribozymes, HDV Rz does not appear

Reprint requests to: Jean-Pierre Perreault, RNA Group/Groupe ARN, Département de Biochimie, Faculté de Médecine et des Sciences de la Santé, Université de Sherbrooke, Sherbrooke QC, J1H 5N4 Canada; e-mail: Jean-Pierre.Perreault@usherbrooke.ca; fax: (819) 564-5340.

Article published online ahead of print. Article and publication date are at http://www.rnajournal.org/cgi/doi/10.1261/rna.963908. able to follow alternative folding pathways, an observation that, at least in part, could be due to the comparatively limited flexibility of its tightly packed structure (Doherty and Doudna 2000; Lévesque et al. 2002; Krasovska et al. 2006). We wondered if it might be possible to alter the activity of a model, antigenomic, $\mathrm{HDV} \mathrm{Rz}$ for which both the kinetic and thermodynamic behaviors have been extensively studied (Mercure et al. 1998; Ouellet and Perreault 2004).

It is well documented that guanine-rich nucleic acid sequences can adopt a four-stranded helical structure termed a "G-quadruplex," in vitro as well as under physiologically ionic conditions (Sen and Gilbert 1988; Keniry 2001; Davis 2004; Saccà et al. 2005; Burge et al. 2006). The primary building block of this structure, called a "G-quartet," is composed of four coplanar guanines that form Hoogsteen base pairs involving a total of eight hydrogen bonds (Gellert et al. 1962). These blocks then stack one on top of another forming a very stable helical G-quadruplex structure. Because each guanine positions its $\mathrm{O}_{6}$ carbonyl group in the center of the G-quartet, there is an absolute requirement for the presence of a counter ion, which typically is potassium (Hardin et al. 1997; Wong and Wu 2003; Neidle and Balasubramanian 2006). 
Here, we report the molecular engineering of a chimeric G-quadruplex-HDV ribozyme. This produced an allosteric ribozyme that is under the control of the potassium, an entirely new class of catalytic RNA. Structural and kinetic characterizations were performed in order to decipher the mechanism that activates this novel ribozyme.

\section{RESULTS AND DISCUSSION}

\section{Engineering a G-quadruplex-HDV ribozyme}

Initially, we decided to use a transacting version of the HDV ribozyme for which the kinetic behavior has been characterized under both single- and multiple-turnover conditions (e.g., see Mercure et al. 1998; Ananvoranich et al. 1999). This antigenomic HDV Rz efficiently cleaves a $5^{\prime}$-end ${ }^{32} \mathrm{P}$-labeled 11 nucleotide (nt) substrate in the presence of $10 \mathrm{mM} \mathrm{MgCl}_{2}$ in $1 \mathrm{~h}$ at $37^{\circ} \mathrm{C}$ regardless of the presence or the absence of either $150 \mathrm{mM} \mathrm{KCl}$ or of an independent RNA aptamer. In the absence of $\mathrm{KCl}$, this aptamer was shown to fold into a rod-like formation of two RNA strands that include several consecutive guanosines joined by a hairpin (Fig. 1A; Lévesque et al. 2007). In the presence of $\mathrm{K}^{+}$, this aptamer was demonstrated to fold into a G-quadruplex structure whose precise structure remains to be solved. When this aptamer was then inserted into the P2 stem of the HDV ribozyme, a stem that is located outside of the catalytic core, cleavage activity was observed only in the presence of $\mathrm{KCl}$ (Fig. 1B, lanes 4,5). In the absence of $\mathrm{KCl}$, only trace amounts of product were detected, suggesting that the Gquadruplex has to be correctly folded in order for the ribozyme to exhibit any cleavage activity. Thus, this newly engineered ribozyme is now a G-quadruplexdependent one (namely, G-quartzyme [GQRz]); that is to say, it represents a new class of Rz.

In order to study the modulation of the ribozyme's activity caused by the introduction of the G-quadruplex structure, several mutants were synthesized
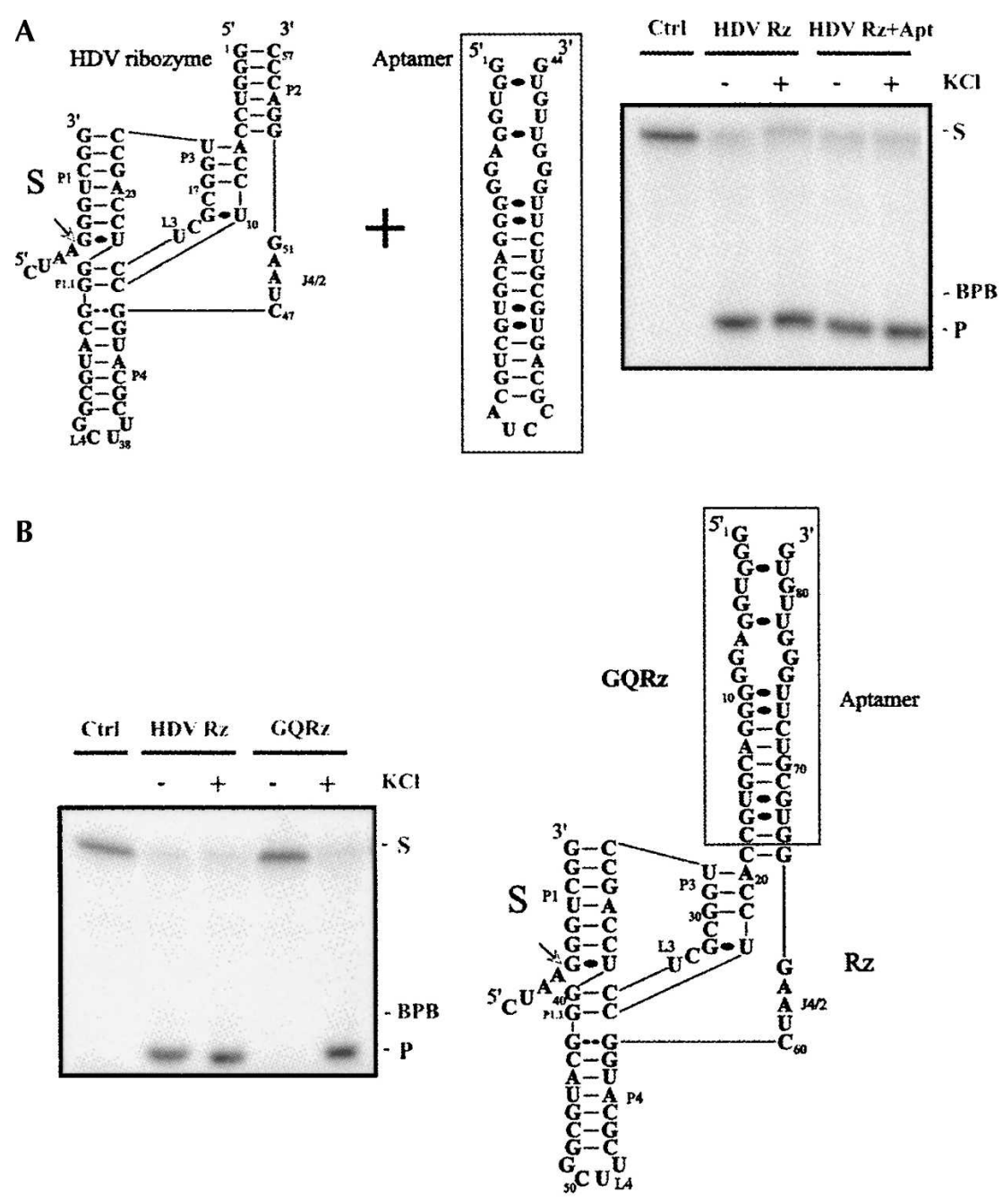

C

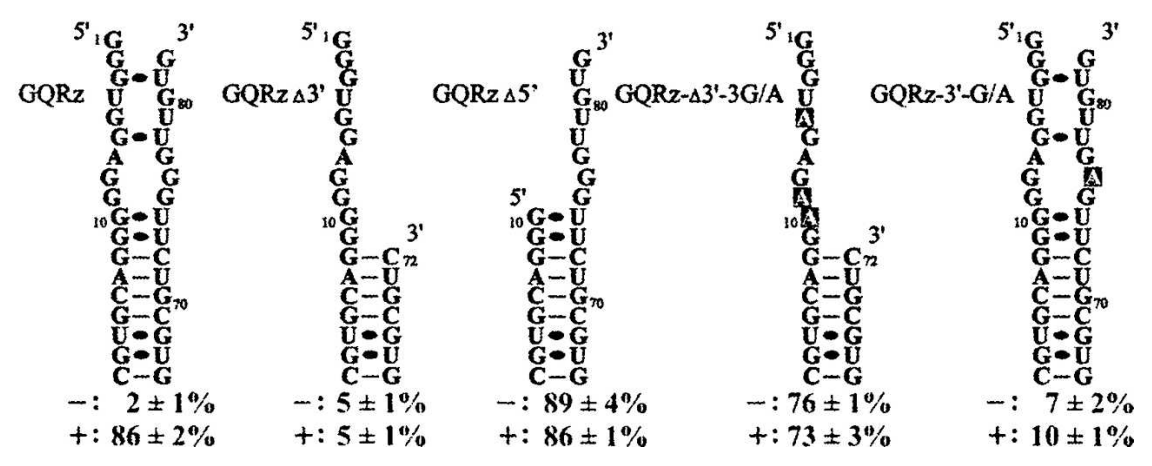

FIGURE 1. (A) Secondary structure and nucleotide sequence of the HDV Rz and (box) the independent RNA aptamer, as well as $(B)$ of the GQRz. The aptamer is illustrated under its inactive structure as previously described (Lévesque et al. 2007). In both cases, autoradiograms of $20 \%$ polyacrylamide gels of cleavage assays performed with $10 \mathrm{nM} \mathrm{Rz}$ either in the presence $(+)$ or absence $(-)$ of $150 \mathrm{mM} \mathrm{KCl}$ are presented. The positions of the substrate (S), product $(\mathrm{P})$, and bromophenol blue marker dye (BPB) are indicated on the right of the gel. The controls (Ctrl) are assays incubated in the absence of any ribozyme. (C) Sequence of the aptamer domain of the mutated GQRz and the percentages of cleavage activities observed after a 1-h incubation of $10 \mathrm{nM}$ ribozyme in either the absence $(-)$ or the presence $(+)$ of $150 \mathrm{mM}$ KCl. (Boxed nucleotides) The mutated positions. 
(Fig. 1C). Deletion of the 3 '-strand of the aptamer domain led to a mutant that retained the low cleavage activity seen in the absence of $\mathrm{KCl}$, but that could not be activated by the addition of $\mathrm{KCl}\left(\mathrm{GQRz}-\Delta 3^{\prime}\right)$. Conversely, deletion of the $5^{\prime}$-strand produced a mutant that is fully active regardless of the presence or absence of $\mathrm{KCl}\left(\mathrm{GQRz}-\Delta 5^{\prime}\right)$. Thus, this $5^{\prime}$-strand of the G-quadruplex seems to be involved in the inhibition. This conclusion receives physical support from the demonstration that the substitution of three guanosines for adenosines in GQRz- $\Delta 3^{\prime}$ led to the generation of a mutant that is active in the absence of $\mathrm{KCl}\left(\mathrm{GQRz}-\Delta 3^{\prime}-3 \mathrm{G} / \mathrm{A}\right)$, showing that it is sequence-specific. Finally, the mutation of a single guanosine in the $3^{\prime}$-strand to an adenosine led to an almost complete loss of the activation caused by the addition of $\mathrm{KCl}$ (GQRz-3'-G/A), illustrating the importance of the guanosines of the $3^{\prime}$-strand in the G-quadruplex formation.

\section{Kinetic characterization of the GQRz}

The kinetic behavior of the GQRz was studied under various single-turnover conditions. In the absence of $\mathrm{KCl}$, it exhibited only residual cleavage in the presence of $50 \mathrm{mM}$ $\mathrm{MgCl}_{2}(<10 \%)$, while the original HDV Rz's cleavage level reached up to $75 \%$ after $30 \mathrm{~min}$ (Fig. 2A). The addition of $\mathrm{K}^{+}$at this point caused a significant increase in the cleavage activity, while the addition of either $\mathrm{Li}^{+}$or $\mathrm{Na}^{+}$, two monovalent ions that do not support formation of this Gquadruplex structure (Lévesque et al. 2007), did not. The addition of $\mathrm{KCl}$ led to cleavage levels equivalent to those of the original HDV Rz. The increased rate was slower than that of the original $\mathrm{Rz}$ because, in this assay, there was no slow-cooling step that favored rapid G-quadruplex formation. Kinetic constants were determined using various concentrations of $\mathrm{Rz}$ (5 to $1600 \mathrm{nM}$ ) and trace amounts of substrate that were initially slow-cooled in the presence of $150 \mathrm{mM} \mathrm{KCl}$ in order to pre-fold the G-quadruplex. GQRz had $k_{\max }$ and $K_{\mathrm{M}^{\prime}}$ values of $0.77 \pm 0.02 \mathrm{~min}^{-1}$ and $42.6 \pm 7.1 \mathrm{nM}$, respectively, compared to $1.24 \pm 0.01 \mathrm{~min}^{-1}$ and $13.6 \pm 1.2 \mathrm{nM}$, respectively, for the original HDV Rz. The difference is likely primarily due to the conformational transition. Both ribozymes had relatively similar magnesium dependencies in the presence of $\mathrm{KCl}$, with $K_{\mathrm{Mg}}$ of $23 \pm 5 \mathrm{mM}$ and $32 \pm 6 \mathrm{mM}$ for the GQRz and original Rz, respectively. The $\mathrm{KCl}$ dependence of the GQRz exhibited a sigmoid relationship characterized by a saturation at $150 \mathrm{mM}$ and a Hill coefficient of $2.9 \pm 0.2$ (Fig. 2B). Thus, this is an allosteric ribozyme whose activity is modulated by $\mathrm{K}^{+}$cations.

It has been well documented that G-quadruplexes are stabilized in the presence of porphyrin. Specifically, it has been demonstrated that the porphyrin generally stacks at the end of the G-quadruplex (Phan et al. 2005; Patel et al. 2007). Moreover, it has been shown that the fusion of a Gquadruplex to a hammerhead structure permitted modulation of the ribozyme cleavage activity by the porphyrin
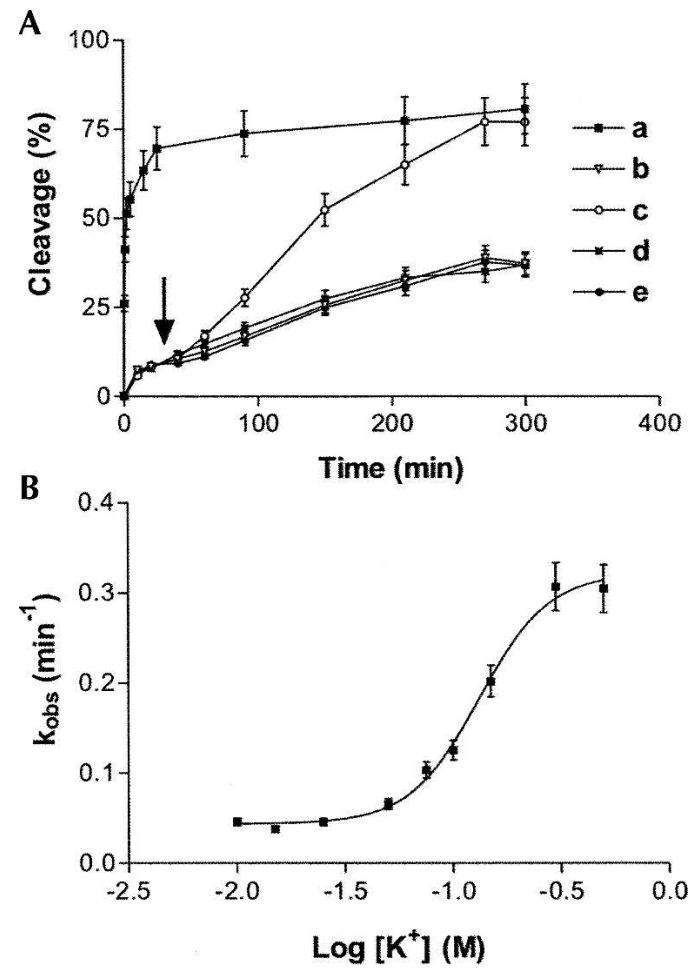

FIGURE 2. Kinetic characterization of the GQRz. (A) Kinetic assays performed under single-turnover conditions- $[\mathrm{Rz} 500 \mathrm{nM}]>[\mathrm{S}<1$ $\mathrm{nM}$ ] - with the HDV Rz (a) and the GQRz after the addition of water (b), $150 \mathrm{mM} \mathrm{KCl} \mathrm{(c),} 150 \mathrm{mM} \mathrm{NaCl}$ (d), or $150 \mathrm{mM} \mathrm{LiCl} \mathrm{(e)} \mathrm{after}$ 30 min of incubation time (arrow mark). (B) Hill representation of cleavage assays using GQRz performed in the presence of 10 to 500 $\mathrm{mM}$ of $\mathrm{KCl}$.

(Wieland and Hartig 2006). The porphyrin was shown to be a novel RNA binder that exhibits the important inhibitory effect of an unmodified hammerhead ribozyme. However, the fusion of a G-quadruplex module to the hammerhead motif led to a ribozyme that turned the strongly inhibitory effect of the porphyrin into an activating one. In accordance with a previous report, it seems that the addition of the G-rich sequences creates a further binding site for the porphyrin. In order to support the idea that GQRz folds into a structure that includes G-quadruplex motifs, cleavage assays were performed in either the presence or the absence of $250 \mathrm{nM} \mathrm{TMPyP} 4$ [meso5,10,15,20-tetrakis-( $N$-methyl-4-pyridyl)porphine, a cationic porphyrin] (Fig. 3A) and various concentrations of $\mathrm{KCl}$. In the case of the original ribozyme, the $k_{\mathrm{obs}} \mathrm{s}$ were virtually identical whether in the absence or the presence of $\mathrm{TMPyP}_{4}$ (Fig. 3B). Only small decreases of the cleavage activity were observed with the increase of $\mathrm{KCl}$, most likely resulting from the $\mathrm{K}^{+}$and $\mathrm{Mg}^{2+}$ competing to bind to the ribozyme. Clearly, the situation was different with the GQRz. Higher concentrations of $\mathrm{KCl}$ were required in the absence of porphyrin in order to obtain the same level of GQRz activity observed in the presence of $\mathrm{TMPyP}_{4}$ 
A
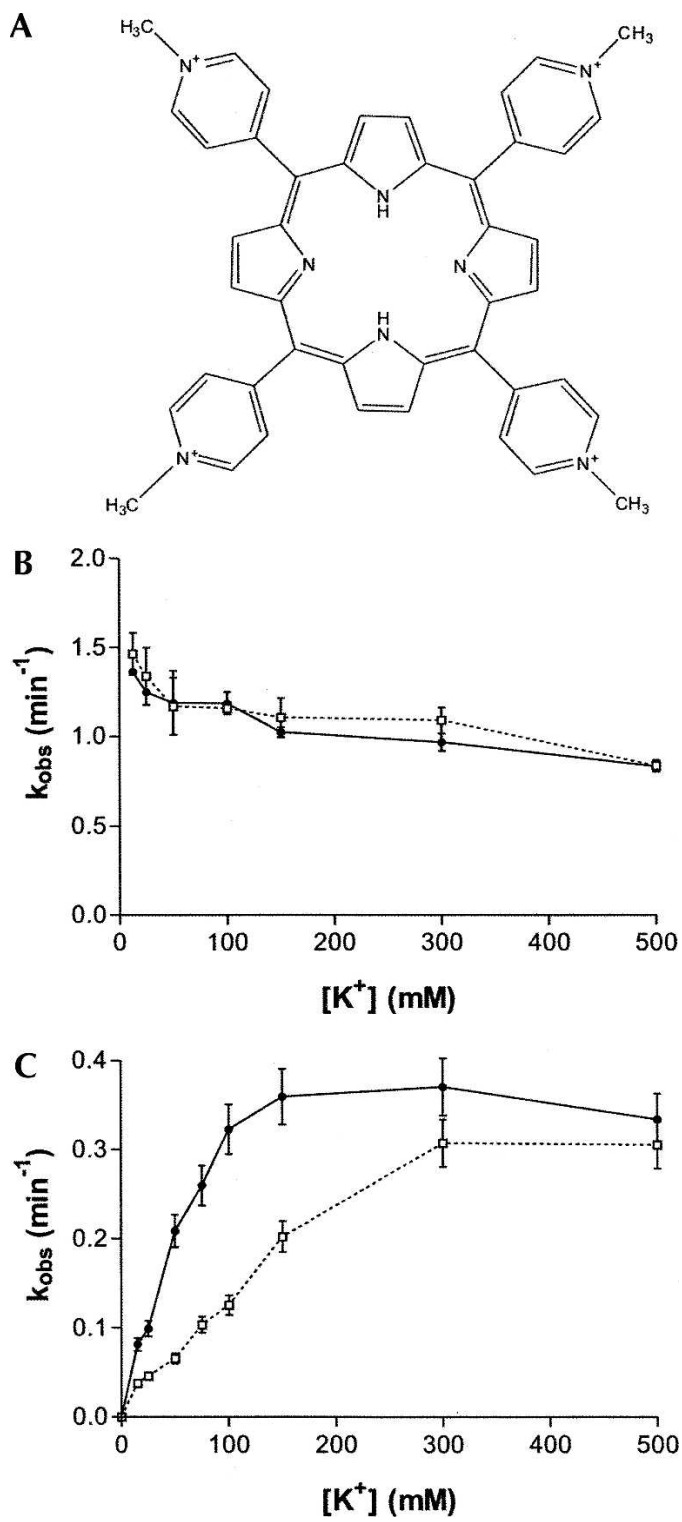

FIGURE 3. Cleavage assays performed either in the absence or presence of porphyrin. (A) Molecular structure of the meso5,10,15,20-tetrakis-( $N$-methyl-4-pyridyl)porphine $\left(\mathrm{TMPyP}_{4}\right) . \quad(B, C)$ Rate constants $\left(k_{\text {obs }}\right)$ of the cleavage activity of the original ribozyme and GQRz, respectively, in various concentrations of $\mathrm{KCl}$ and either (opened squares) the absence or (closed circles) the presence of

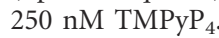

(Fig. 3C). Moreover, kinetic analysis revealed that the Hill constant was reduced from 2.9 to 1.9 in the presence of $\mathrm{TMPyP}_{4}$. These results support the formation of the G-quadruplex in the on state of the GQRz. Several experiments were performed to establish whether the G-quadruplex was resulting from intra- or from intermolecular interactions (data not shown). For example, the active GQRz was incubated with increasing concentration of the original aptamer, or inactive GQRz (resulting from mutations in the catalytic core of the ribozyme domain), and kinetics of cleavage performed. All the data obtained with or without prior heat denaturation-renaturation support the idea that the G-quadruplex results from intramolecular interactions; therefore, GQRz would act as a monomer.

\section{Probing the conformational transition}

Structural differences caused by the addition of the $\mathrm{K}^{+}$ions were revealed by probing the guanosines. A typical autoradiogram for the ribonuclease $\mathrm{T} 1$ probing (RNase $\mathrm{T} 1$, an enzyme that preferentially cleaves single-stranded guanosines) of 5'-end-labeled GQRz is shown in Figure 4A. The observed banding pattern is virtually identical to that obtained when the GQRz was incubated in the presence of $150 \mathrm{mM}$ either $\mathrm{LiCl}$ or $\mathrm{NaCl}$. However, upon the addition of $150 \mathrm{mM} \mathrm{KCl}$, several differences were observed. For example, the phosphodiester bonds of the guanosines located in positions $75,76,77$, and 80 were no longer hydrolyzed. Data from several experiments using either $5^{\prime}$ - or $3^{\prime}$-end-labeled GQRz were compiled (Fig. 4B). Briefly, this analysis led to two conclusions: (1) globally, the structure of the ribozyme domain is in agreement with the proposed secondary structure, regardless of the presence or the absence of the $\mathrm{KCl}$ (i.e., all of the singlestranded guanosines were hydrolyzed, with the exception of those located in positions 40 to 42 that appear to be singlestranded only after the addition of $\mathrm{KCl}$ even though they should be single-stranded under both conditions); and (2) the guanosines from the upper part of the aptamer domain were not hydrolyzed in the presence of $\mathrm{KCl}$, supporting the notion that they are involved in the formation of the G-quadruplex. This hypothesis also received support from the observation that these guanosines were protected from DMS modification solely in the presence of $\mathrm{KCl}$ (see Fig. 4B). Figure 4C shows a autoradiogram of a DMS probing performed with the 3 '-end-labeled GQRz. Specifically, this shows that the guanosine residues in positions $3,5,6,8,9,10$, and 11 were protected from the DMS modification solely in the presence of $\mathrm{K}^{+}$.

\section{Studies of the inactive conformation}

The addition of $\mathrm{KCl}$ to GQRz has the effect of supporting a structural transition from an inactive (off state) to an active (on state) conformation of the ribozyme domain due to the formation of a G-quadruplex structure. It is likely that this transformation is possible because the formation of a G-quadruplex has been shown to compete favorably with the maintenance of existing Watson-Crick base pairs (Li et al. 2003).

The nature of the off state remains unclear; however, nuclease probing and sequence analysis suggested two possibilities that were subsequently verified by site-directed mutagenesis. First, RNase T1 data revealed that the guanosines located in positions 40 to 42 that form the J1/4 junction 

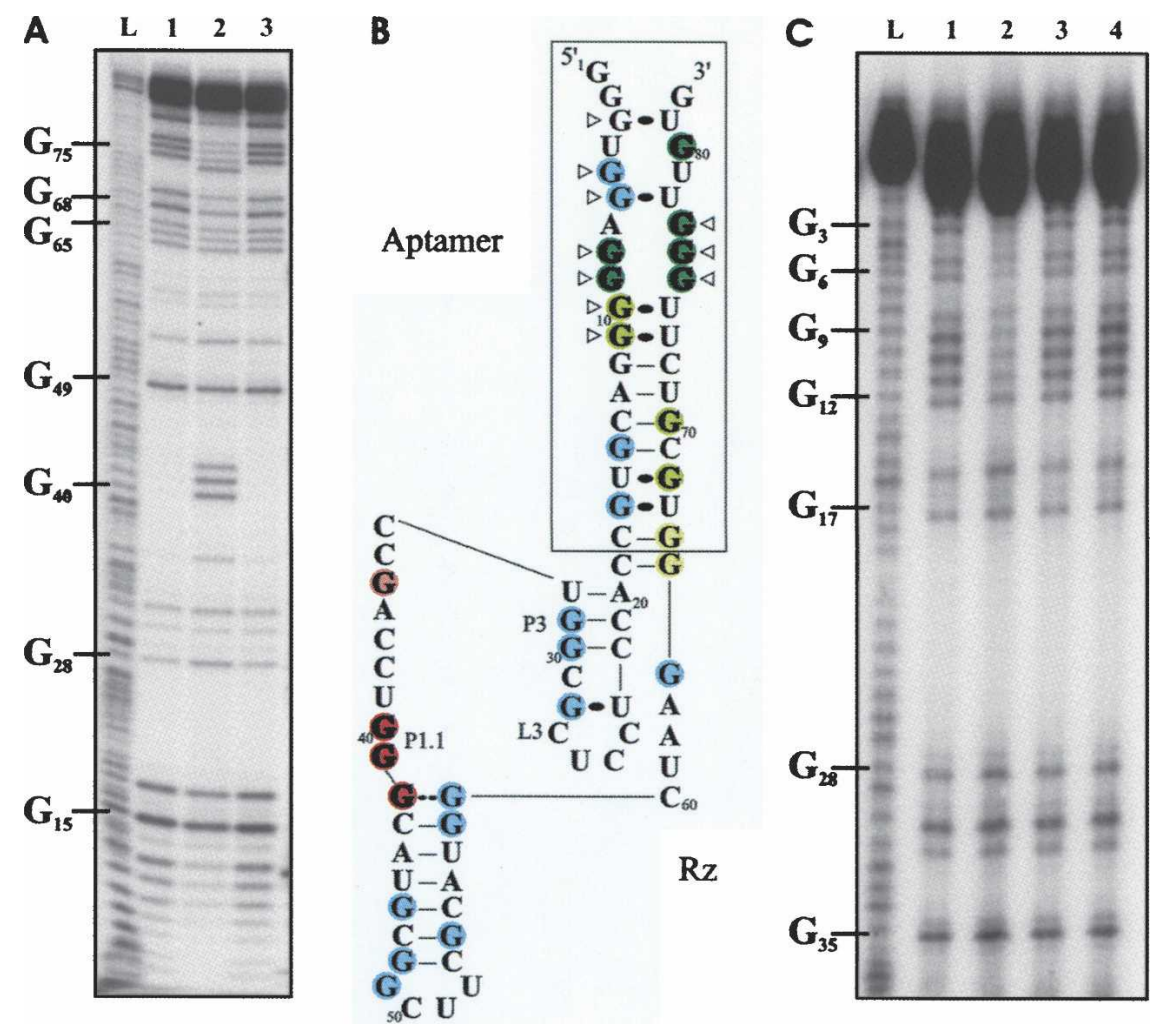

FIGURE 4. Structural characterization of the GQRz. (A) Autoradiogram of a $8 \%$ denaturing (8 M urea) polyacrylamide gel of RNase T1 mapping of 5'-labeled GQRz performed in the presence of $150 \mathrm{mM}$ (lane 1) $\mathrm{NaCl}$, (lane 2) $\mathrm{KCl}$, or (lane 3) $\mathrm{LiCl}$. Representative guanosine residues are indicated on the left of the gel. (Lane L) An alkaline hydrolysis of GQRz. (B) Compilation of the mapping data. The circled guanosines were hydrolyzed by RNase T1 specifically in the (green) absence or (red) presence of $\mathrm{KCl}$, or (blue) under both conditions. The intensity of the color and the thickness of the characters are proportional to the relative amount of cleavage observed. (Triangles) The guanosines protected from the DMS reagent in the presence of $\mathrm{KCl}$. (C) Autoradiogram of an $8 \%$ denaturing ( $8 \mathrm{M}$ urea) polyacrylamide gel of DMS probing performed with the $3^{\prime}$-end-labeled GQRz in either (lane 1) the absence of monovalent salt or the presence of $150 \mathrm{mM}$ (lane 2) $\mathrm{KCl}$, (lane 3) $\mathrm{NaCl}$, or (lane 4) $\mathrm{LiCl}$.

that is single-stranded in the absence of substrate, a fact that is well supported by published data (e.g., see Ouellet and Perreault 2004), are not hydrolyzed in the off state, suggesting that they were either in a helical region or not accessible (Fig. 4A). This might result from an interaction between nucleotides 1 to 7 of the aptamer domain and nucleotides 33 to 39 of the ribozyme domain as, with the exception of one residue, they are complementary. Two ribozymes mutated in the $\mathrm{P} 1 \mathrm{stem}$, and the appropriate complementary substrates, were synthesized and their cleavage activities accessed (Fig. 5A-C,F). The mutants that could not support the formation of the potential interaction exhibited cleavage activities similar to that of the original sequence, thereby invalidating this hypothesis (Fig. 5F). Figure $5 \mathrm{~F}$ illustrates the results of the relative end point determined for the GQRz mutant as compared to the original HDV ribozyme having the same mutations. Analysis of the $k_{\mathrm{obs}}$ values led to the same conclusion. Finally, a binding shift assay showed that the substrate bound to the
GQRz in the absence of $\mathrm{KCl}$, consequently, suggesting that the $\mathrm{P} 1$ region is not involved in the inhibitory mechanism (data not shown).

Second, nucleotides 6-12 of the aptamer can base pair with nucleotides 21-27 of the P3-L3 stem-loop (Fig. 5D). This binding is supported by RNase A probing experiments (data not shown), which preferentially hydrolyze single-stranded $\mathrm{C}$ and $\mathrm{U}$ residues, suggesting that positions $\mathrm{C}_{21}$ to $\mathrm{U}_{26}$ were single-stranded in the on state, but not in the off state. Based on results from in vitro selection showing potential sequence variations in this region (Nehdi et al. 2007), a mutant GQRz was produced and tested (Fig. 5E,F). The resulting GQRz-mutP3L3 showed a significant increase in its cleavage activity in the absence of $\mathrm{KCl}$ as compared to that of the original ribozyme, supporting the hypothesis that the off state was due to this second potential interaction. The formation of this interaction may also support a different folding of the P1 stem, which would be responsible for the non-hydrolysis of the J1/4 guanosines by the RNase T1 (e.g., ${ }_{31} \mathrm{GUCCG}_{35}$ with ${ }_{39} \mathrm{UGGGC}_{43}$ ).

\section{Concluding remark}

Altogether, these results led us to propose a model for the GQRz modulation in which the addition of the effector $\mathrm{KCl}$ supports a structural transition from an inactive (off state) to an active (on state) conformation of the ribozyme domain that depends on the formation of a G-quadruplex (see Fig. 6). The nature of the off state remains unclear; however, preliminary experiments suggest that it likely results from base-pairing interactions between the $5^{\prime}$-strand of the aptamer domain and the P3-L3 stem-loop of the ribozyme domain. This study shows that it is possible to interfere with the tightly structured HDV Rz by the addition of an unusual structure. To our knowledge, the GQRz is the sole ribozyme possessing a monovalent cation-dependent activity.

\section{MATERIALS AND METHODS}

\section{RNA synthesis}

All ribozymes were synthesized by in vitro transcription using T7 RNA polymerase as described previously (Nehdi et al. 2007). Briefly, two overlapping oligonucleotides $(2 \mu \mathrm{M}$ each) were 


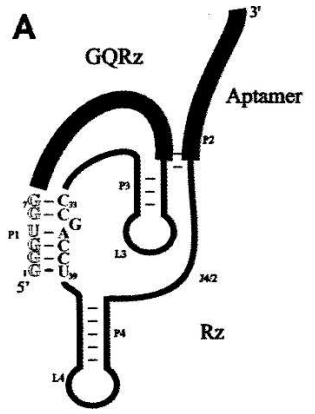

B

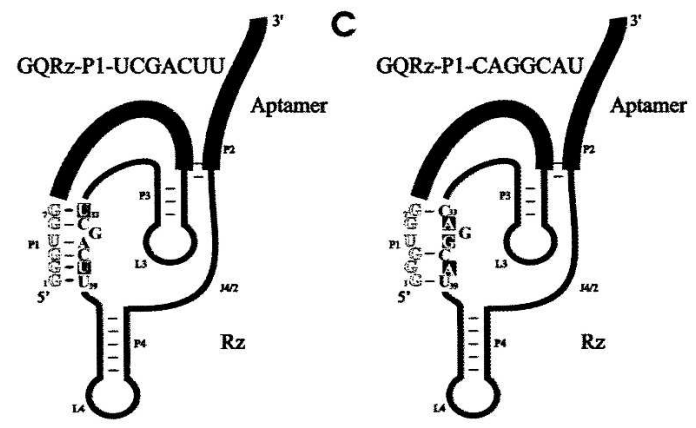

D
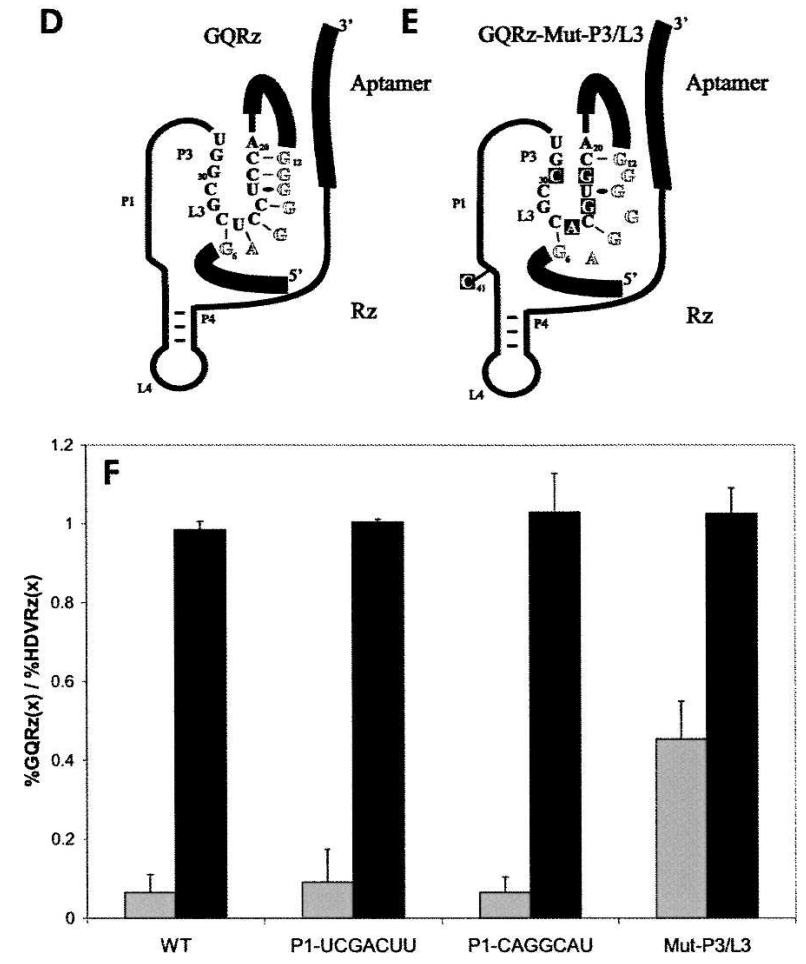

FIGURE 5. Cleavage assays performed with GQRz mutated in either the P1 stem or the P3-L3 stem-loop. $(A-C)$ Schematic secondary structures showing the potential base-pairing between the $5^{\prime}$-strand of the aptamer domain and the $\mathrm{P} 1$ region of the ribozyme domain either in $(A)$ the original GQRz or $(B, C)$ the two mutated versions. $(D, E)$ Schematic secondary structures showing the potential base-pairing between the $5^{\prime}$-strand of the aptamer domain and the P3-L3 region of the ribozyme domain. In all cases, the mutated nucleotides are boxed, and the aptamer is always represented under its inactive conformation. $(F)$ Relative cleavage activities for the three versions after a $1 \mathrm{~h}$ of incubation at $37^{\circ} \mathrm{C}$ under single-turnover conditions $(100 \mathrm{nM} \mathrm{Rz}$ and $1 \mathrm{nM} \mathrm{S}$ ) either in (black bars) the presence or (light gray bars) the absence of $150 \mathrm{mM} \mathrm{KCl}$. annealed, and double-stranded DNA was obtained by filling in the gaps using purified $P f u$ DNA polymerase. The double-stranded DNA was then ethanol-precipitated. The resulting DNA templates contained the T7 RNA promoter sequence followed by the ribozyme sequence. After dissolution in ultrapure water, run-off transcriptions were carried out in a final volume of $100 \mu \mathrm{L}$ containing purified T7 RNA polymerase $(10 \mu \mathrm{g})$ in the presence of RNA Guard (24 U; Amersham Biosciences), pyrophosphatase (0.01 U; Roche Diagnostics), and $5 \mathrm{mM}$ NTP in a buffer containing $80 \mathrm{mM}$ HEPES-KOH (pH 7.5), $24 \mathrm{mM} \mathrm{MgCl}_{2}, 2 \mathrm{mM}$ spermidine, and $40 \mathrm{mM} \mathrm{DTT}$, and using the double-stranded DNA as template. After a $2-\mathrm{h}$ incubation at $37^{\circ} \mathrm{C}$, the mixtures were treated with DNase RQ1 (Promega) for $20 \mathrm{~min}$ at $37^{\circ} \mathrm{C}$, and the RNA was then purified by phenol:chloroform extraction followed by precipitation with ethanol. The transcripts were fractionated by denaturing ( $8 \mathrm{M}$ urea) $8 \%$ polyacrylamide gel electrophoresis (PAGE; 19:1 ratio of acrylamide to bisacrylamide) using $45 \mathrm{mM}$ Tris-borate $(\mathrm{pH}$ 7.5)/1 mM EDTA solution as running buffer. The RNAs were visualized by UV shadowing. The bands corresponding to the correct sizes of the ribozymes were excised from the gel and the transcripts eluted overnight at room temperature in buffer containing $1 \mathrm{mM}$ EDTA, 0.1\% SDS, and $0.5 \mathrm{M}$ ammonium acetate. The ribozymes were then ethanolprecipitated, dried, and dissolved in water. The concentrations were determined by absorbance at $260 \mathrm{~nm}$. Chemically synthesized ribo-oligonucleotides (RNA substrates: 5'-CUAAGGGUC GG-3', 5'-CUAAGAGUCGA-3', and 5'-CUAAGUGCCUG-3') were purchased from Integrated DNA Technologies (IDT).

\section{RNA labeling}

In order to produce 5 '-end-labeled ribozymes, transcripts were dephosphorylated by adding $1 \mathrm{U}$ of antartic phosphatase (New England Biolab) to $50 \mathrm{pmol}$ of ribozyme and incubating the reaction mixture for $30 \mathrm{~min}$ at $37^{\circ} \mathrm{C}$ in a final volume of $10 \mu \mathrm{L}$ containing $50 \mathrm{mM}$ Bis-Propane (pH 6.0), $1 \mathrm{mM} \mathrm{MgCl} 2,0.1 \mathrm{mM}$ $\mathrm{ZnCl}_{2}$, and $40 \mathrm{U}$ of RNAGuard (Amersham Biosciences). The enzyme was then inactivated by incubation for $5 \mathrm{~min}$ at $65^{\circ} \mathrm{C}$. Dephosphorylated ribozymes (10 pmol), or chemically synthesized RNA substrates, were $5^{\prime}$-end-radiolabeled using $3 \mathrm{U}$ of T4 polynucleotide kinase (Promega) for $1 \mathrm{~h}$ at $37^{\circ} \mathrm{C}$ in the presence of $3.2 \mathrm{pmol}$ of $\left[\gamma^{-}{ }^{32} \mathrm{P}\right]$ ATP $(6000 \mathrm{Ci} / \mathrm{mmol}$; New England Nuclear). The reactions were stopped by the addition of ice-cold formamide dye buffer (95\% formamide, 10 mM EDTA, 0.025\% bromophenol blue, and $0.025 \%$ xylene cyanol), and the RNA molecules were purified by $8 \%-20 \%$ polyacrylamide gel electrophoresis and recovered as described above except that the detection was performed by autoradiography. For the $3^{\prime}$-end labeling of ribozymes, $15 \mathrm{pmol}$ were incubated for $1 \mathrm{~h}$ at $37^{\circ} \mathrm{C}$ in a final volume of $10 \mu \mathrm{L}$ containing $50 \mathrm{mM}$ Tris- $\mathrm{HCl}(\mathrm{pH} 7.8), 10 \mathrm{mM} \mathrm{MgCl}, 10 \mathrm{mM}$ DTT, $1 \mathrm{mM}$ ATP, $10 \%$ dimethylsulfoxide, 10 pmol $\left[{ }^{32} \mathrm{P}\right] \mathrm{Cp}$ (3000 Ci/mmol; New England Nuclear), and $10 \mathrm{U}$ of T4 RNA ligase (New England Biolabs). After incubation, the ribozymes were purified on denaturing gels and recovered as described above.

\section{Cleavage reactions and kinetics}

Unless otherwise stated, the cleavage reactions were carried out in $20-\mu \mathrm{L}$ reaction mixtures containing $50 \mathrm{mM}$ Tris- $\mathrm{HCl}(\mathrm{pH} 7.5)$ either in the presence or the absence of $150 \mathrm{mM} \mathrm{KCl}$ and $10 \mathrm{mM}$ 


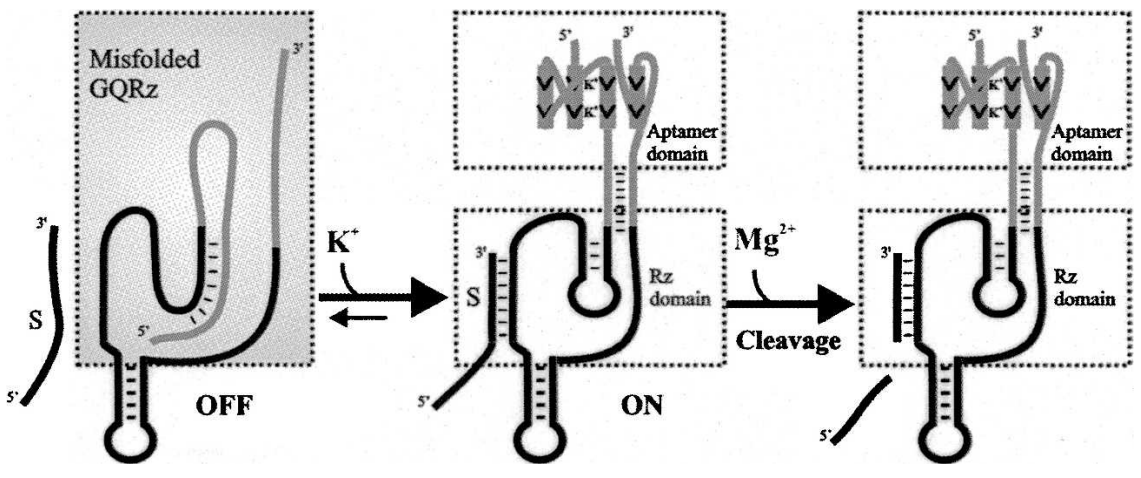

FIGURE 6. Model of the molecular mechanism of the GQRz.

nonradioactive ribozyme and dissolved in $10 \mu \mathrm{L}$ of buffer containing $20 \mathrm{mM}$ Tris- $\mathrm{HCl}$ ( $\mathrm{pH}$ 7.5), $10 \mathrm{mM} \mathrm{MgCl}_{2}$, and either $150 \mathrm{mM}$ $\mathrm{NaCl}, \mathrm{KCl}$, or $\mathrm{LiCl}$. The ribozymes were heat-denatured and slow-cooled prior to the addition of the magnesium. The mixtures were incubated for $2 \mathrm{~min}$ at $37^{\circ} \mathrm{C}$ in the presence of $0.6 \mathrm{U}$ of RNase $\mathrm{T} 1$ (Roche Diagnostic), and were then quenched by the addition of $10 \mu \mathrm{L}$ of ice-cold formamide dye buffer. For alkaline hydrolysis, the ribozymes $(<1 \mathrm{nM})$ were dissolved in $5 \mu \mathrm{L}$ of water, $1 \mu \mathrm{L}$ of $1 \mathrm{~N} \mathrm{NaOH}$ was added, and the reaction was incubated for $1 \mathrm{~min}$ at room temperature prior to being quenched by the addition of $3 \mu \mathrm{L}$ of $1 \mathrm{M}$ Tris- $\mathrm{HCl}$ ( $\mathrm{pH}$

$\mathrm{MgCl}_{2}$ for $1 \mathrm{~h}$ at $37^{\circ} \mathrm{C}$ under single-turnover conditions $([\mathrm{Rz}] \gg$ $[\mathrm{S}])$. Prior to the reactions, trace amounts of $5^{\prime}-{ }^{32} \mathrm{P}$-end-labeled substrates $(<1 \mathrm{nM})$ and nonradioactive ribozymes $(10 \mathrm{nM})$ were mixed together in the Tris- $\mathrm{HCl}$ buffer and $\mathrm{KCl}$ (depending on the experiment), heated for $2 \mathrm{~min}$ at $70^{\circ} \mathrm{C}$, slow-cooled to room temperature, and then incubated for $5 \mathrm{~min}$ at $37^{\circ} \mathrm{C}$. The cleavage reactions were initiated by the addition of $\mathrm{MgCl}_{2}$. After an incubation of $1 \mathrm{~h}$ at $37^{\circ} \mathrm{C}$, the reactions were quenched by the addition of ice-cold formamide dye buffer. The mixtures were fractionated on denaturing 20\% PAGE gels and exposed to PhosphorImager screens (Molecular Dynamic). The extents of cleavage were determined from measurements of the radioactivity present in both the substrate and the $5^{\prime}$ product bands using the ImageQuant software. For time-course experiments, aliquots of $2.3 \mu \mathrm{L}$ were taken at various times up to $1 \mathrm{~h}(5 \mathrm{~h}$ for the experiments that were not slow-cooled experiments) and were treated as described above.

Kinetic analyses were performed under single-turnover conditions in the presence of $50 \mathrm{mM} \mathrm{MgCl}$ and $150 \mathrm{mM} \mathrm{KCl}$. Trace amounts of $5^{\prime}{ }^{32} \mathrm{P}$-end labeled substrate $(<1 \mathrm{nM})$ were cleaved using various concentrations of ribozyme (5-1600 nM), $\mathrm{MgCl}_{2}$ (1-100 $\mathrm{mM})$, or $\mathrm{KCl}(10-500 \mathrm{mM})$. Cleavage assays with various concentrations of $\mathrm{KCl}$ were also performed in the presence of the $250 \mathrm{nM} \mathrm{TMPyP}$ (Calbiochem). The fractions cleaved were determined and the rate of cleavage $\left(k_{\mathrm{obs}}\right)$ was obtained from fitting the data to the equation $A_{\mathrm{t}}=A_{0}\left(1-e^{-k t}\right)$, where $A_{t}$ is the percentage of cleavage at time $t, A_{0}$ is the maximum percent cleavage (or the end point of cleavage), and $k$ is the rate constant $\left(k_{\text {obs }}\right)$. Each rate constant was calculated from at least two independent measurements. The values of $k_{\mathrm{obs}}$ obtained were then plotted as a function of either the ribozyme or the $\mathrm{Mg}^{2+}$ concentration for the determination of $k_{\max }, K_{\mathrm{M}^{\prime}}$ (i.e., a pseudoMichealis Menten constant that is more appropriate than a $K_{\mathrm{D}}$ because the kinetic mechanism of HDV ribozyme involves several conformational transitions), and $K_{\mathrm{Mg}}$. Using the GraphPad Prism software, the Hill coefficient was calculated by curve fitting using a sigmoidal dose-response with variable slope: $Y=$ Bottom + (Top Bottom $) /\left(1+10^{[(\operatorname{LogEC} 50-X) \text { Hillslope }]}\right)$, where $Y$ is the $k_{\text {obs }}$ and $X$ is the logarithm of the $\mathrm{KCl}$ concentration in molar. The values obtained from independent experiments varied by less than $15 \%$.

\section{Enzymatic and chemical probing}

RNase T1 probing was carried out with trace amounts of the $5^{\prime}$ ${ }^{32} \mathrm{P}$-end-labeled ribozyme (<1 nM) supplemented with $1.5 \mu \mathrm{M}$
7.5). The RNA molecules were then ethanol-precipitated and dissolved in loading buffer. All samples were analyzed on denaturing $8 \%$ PAGE gels and visualized by exposure to PhosphorImager screens. For chemical probing, $1 \mu \mathrm{L}$ of DMS (dimethyl sulfate; diluted 1:8 in 100\% ethanol) was added to the sample and then incubated for a further $20 \mathrm{~min}$ at room temperature. The RNA samples were ethanol-precipitated and the pellets washed twice with ethanol in order to remove all traces of DMS. The resulting pellets were dissolved in $20 \mu \mathrm{L}$ of $500 \mathrm{mM}$ Tris/ $\mathrm{HCl}(\mathrm{pH} \mathrm{7.5)}$. Sodium borohydride ( $200 \mathrm{mM} ; 10 \mu \mathrm{L}$ ) was added to the samples, which were then kept on ice for $5 \mathrm{~min}$ in the dark. Next, $10 \mu \mathrm{L}$ of aniline solution (aniline/glacial acetic acid/water, 10:6:93, by volume) was added to the samples, and the tubes were incubated for $10 \mathrm{~min}$ at $60^{\circ} \mathrm{C}$ in the dark. The ribozyme was then ethanolprecipitated, fractionated on denaturing PAGE, and analyzed.

\section{ACKNOWLEDGMENTS}

This work was supported by a grant from the Canadian Institutes of Health Research (CIHR, MOP-44002) to J.-P.P. The RNA group is supported by a grant from the CIHR and the Universite de Sherbrooke. J.-D.B. was supported by a pre-doctoral fellowship from CIHR. J.-P.P. holds the Canada Research Chair in Genomics and Catalytic RNA.

Received December 17, 2007; accepted March 1, 2008.

\section{REFERENCES}

Ananvoranich, S., Lafontaine, D.A., and Perreault, J.P. 1999. Mutational analysis of the antigenomic trans-acting $\delta$ ribozyme: The alteration of the middle nucleotides located on the P1 stem. Nucleic Acids Res. 27: 1473-1479. doi: 10.1093/nar/27.6.1473.

Burge, S., Parkinson, G.N., Hazel, P., Todd, A.K., and Neidle, S. 2006. Quadruplex DNA: Sequence, topology and structure. Nucleic Acids Res. 34: 5402-5415. doi: 10.1093/nar/gkl655.

Davis, J.T. 2004. G-quartets 40 years later: From $5^{\prime}$-GMP to molecular biology and supramolecular chemistry. Angew. Chem. Int. Ed. Engl. 43: 668-698.

Doherty, E.A. and Doudna, J.A. 2000. Ribozyme structures and mechanisms. Annu. Rev. Biochem. 69: 597-615.

Gellert, M., Lipssett, M.N., and Davies, D.R. 1962. Helix formation by guanylic acid. Proc. Natl. Acad. Sci. 48: 2013-2018.

Hardin, C.C., Corregan, M.J., Lieberman, D.V., and Brown, B.A. 1997. Allosteric interactions between DNA strands and monovalent 
cations in DNA quadruplex assembly: Thermodynamic evidence for three linked association pathways. Biochemistry 36: 1542815450.

Keniry, M.A. 2001. Quadruplex structures in nucleic acids. Biopolymers 56: 123-146.

Krasovska, M.V., Sefcikova, J., Reblova, K., Schneider, B., Walter, N.G., and Sponer, J. 2006. Cations and hydration in catalytic RNA: Molecular dynamics of the hepatitis delta virus ribozyme. Biophys. J. 91: 626-638.

Lévesque, D., Choufani, S., and Perreault, J.P. 2002. Delta ribozyme benefits from a good stability in vitro that becomes outstanding in vivo. RNA 8: 464-477.

Lévesque, D., Beaudoin, J.D., Roy, S., and Perreault, J.P. 2007. In vitro selection and characterization of RNA aptamers binding thyroxine hormone. Biochem. J. 403: 129-138.

Li, W., Miyoshi, D., Nakano, S., and Sugimoto, N. 2003. Structural competition involving G-quadruplex DNA and its complement. Biochemistry 42: 11736-11744.

Mercure, S., Lafontaine, D.A., Ananvoranich, S., and Perreault, J.P. 1998. Kinetic analysis of $\delta$ ribozyme cleavage. Biochemistry 37: 16975-16982.

Nehdi, A., Perreault, J., Beaudoin, J.D., and Perreault, J.P. 2007. A novel structural rearrangement of hepatitis delta virus antigenomic ribozyme. Nucleic Acids Res. 35: 6820-6831. doi: 10.1093/nar/ gkm674.

Neidle, S. and Balasubramanian, S. 2006. Quadruplex nucleic acids. RSC Publishing, Cambridge, UK.
Ouellet, J. and Perreault, J.P. 2004. Cross-linking experiments reveal the presence of novel structural features between a hepatitis $\delta$ virus ribozyme and its substrate. RNA 10: 1059-1072.

Patel, D.J., Phan, A.T., and Kuryavyi, V. 2007. Human telomere, oncogenic promoter and 5'-UTR G-quadruplexes: Diverse higher order DNA and RNA targets for cancer therapeutics. Nucleic Acids Res. 35: 7429-7455. doi: 10.1093/nar/gkm711.

Phan, A.T., Kuryavyi, V., Gaur, H.Y., and Patel, D.J. 2005. Smallmolecule interaction with a five-guanine-tract G-quadruplex structure from the human MYC promoter. Nat. Chem. Biol. 1: 167-173.

Saccà, B., Lacroix, L., and Mergny, J.L. 2005. The effect of chemical modifications on the thermal stability of different G-quadruplexforming oligonucleotides. Nucleic Acids Res. 33: 1182-1192. doi: 10.1093/nar/gki257.

Sen, D. and Gilbert, W. 1988. Formation of parallel four-stranded complexes by guanine-rich motifs in DNA and its implications for meiosis. Nature 334: 364-366.

Shih, I.H. and Been, M.D. 2002. Catalytic strategies of the hepatitis delta virus ribozymes. Annu. Rev. Biochem. 71: 887-917.

Wieland, M. and Hartig, J.S. 2006. Turning inhibitors into activators: A hammerhead ribozyme controlled by a guanine quadruplex. Angew. Chem. Int. Ed. Engl. 45: 5875-5878.

Wong, A. and Wu, G. 2003. Selective binding of monovalent cations to the stacking G-quartet structure formed by guanosine $5^{\prime}$ monophosphate: A solid-state NMR study. J. Am. Chem. Soc. 125: 13895-13905. 

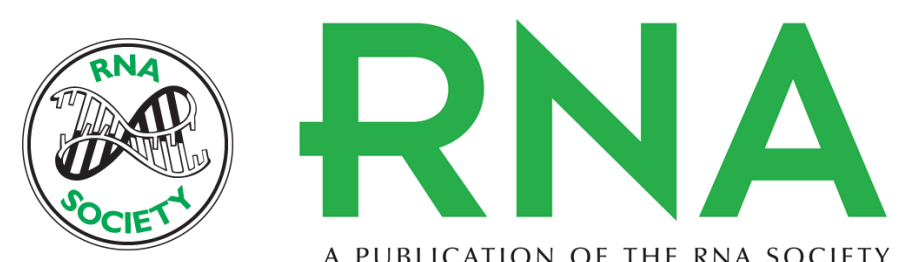

A PUBLICATION OF THE RNA SOCIETY

\title{
Potassium ions modulate a G-quadruplex-ribozyme's activity
}

\author{
Jean-Denis Beaudoin and Jean-Pierre Perreault
}

RNA 2008 14: 1018-1025

References This article cites 21 articles, 4 of which can be accessed free at: http://rnajournal.cshlp.org/content/14/6/1018.full.html\#ref-list-1

Open Access Freely available online through the RNA Open Access option.

License Freely available online through the open access option.

Email Alerting Receive free email alerts when new articles cite this article - sign up in the box at the Service top right corner of the article or click here. 